\title{
Genetic Systems and Variations of Isozymes in Wild Taro (Colocasia esculenta Schott) from Bangladesh
}

\author{
Shiro Isshiki, Masahiro Nakada, Noriyoshi Nakamura, Yosuke Tashiro and Sadami Miyazaki \\ Faculty of Agriculture, Saga University, Saga 840
}

\begin{abstract}
Summary
Mode of inheritance of isozyme variations for aspartate aminotransferase (AAT), shikimate dehydrogenase (SKDH) and glucose-6-phosphate isomerase (GPI) were studied using the progenies of wild taros introduced from Bangladesh. Genetic variations were observed among the wild diploids and triploids for the isozyme loci.

Through the segregations of the isozyme phenotypes in the five progeny populations obtained from artificial crosses, and the observation of diploid accessions, three isozyme loci, Aat-1. Skdh and Gpi-2 were identified and the presence of two alleles both at Aat-1 and $S k d h$ and three alleles at Gpi-2 are inferred. No evidence for linkage was detected between the three loci. These isozyme patterns are inherited in Mendelian manner and are expected to be useful as genetic markers for studying the genetics, systematics, and breeding of taro. The triploid accessions were found to contain the same alleles that are possessed by the diploid accessions at all the three loci. This suggests that the component genomes of the triploids are the same as those of the diploids. Therefore, the triploid wild taros from Bangladesh are postulated to have originated from diploid ones.
\end{abstract}

\section{Introduction}

Taro (Colocasia esculenta (L.) Schott) is an important edible crop which is cultivated mainly in the South Pacific region, Asia, and Africa. The cultivated taro is considered to have originated in south-central Asia, probably in India or Malaysia (Plucknett et al., 1970). In Japan, limited parts, i.e., corms, cormels and petioles of taro, have been used for food, whereas, in the other regions of the world, stolons, leaf blades and spadices of taro are also consumed. Therefore, in the breedings of taro in Japan, it is important to improve characters of not only corms, cormels and petioles but also the other parts of the plant by using the broad genetic resources, including wild plants. For the breeding, fundamental genetic studies on wild taros as well as cultivated ones would be necessary.

In our laboratory, wild taro accessions introduced from Bangladesh are preserved as germplasm resources for taro breeding. These accessions growing in the wetlands of Bangladesh sel-

Received for publication 17 August 1994. dom develop corms and cormels but produce stolons instead. The wild taro plants have large leaf blades and petioles and bear flowers and fruits with fertile seeds readily under Japanese climatic conditions. Locating genetic markers in the wild taro would accelerate the breeding project in which they are used as parental materials.

It is known that there are diploids $(2 \mathrm{n}=2 \mathrm{x}=$ 28 ) and triploids $(2 n=3 x=42)$ in taro (Coates et al., 1988; Kuruvilla and Singh, 1981; Tanimoto and Matsumoto, 1986), however, the comprehen sive genetic relationship between the diploids and triploids has not been established to date. Our chromosome survey clarified that there are diploids and triploids in the wild accessions from Bangladesh (unpublished data). Since the wild populations of taro in Bangladesh seem to have escaped artificial selection and transfer, these wild accessions would be excellent materials for studying the genetic relationship between diploid and triploid taros.

Genetic variations of isozymes were successfully used for characterizing cultivated and wild accessions of taro (Lebot and Aradhya, 1991, 1992; 
Tanimoto and Matsumoto, 1986). Additional isozyme analyses may clarify the genetic relationship between wild taro plants exhibiting diploidy and triploidy because the inheritance mode of isozyme variations between them had yet to be established. In the present study, genetic systems and variations of three isozyme genes were analyzed to find the well defined genetic markers in the wild taro accessions from Bangladesh. Furthermore, based on the genetic variations observed in the wild taros, we discuss the relationship between the diploid and triploid taro accessions from Bangladesh.

\section{Materials and Methods}

Sixty-nine wild taro clones, which were growing in the wetlands in Bangladesh, were collected, and introduced into our laboratory where they were examined for isozyme variations. Thirty eight were diploids and 31 were triploids. Six clones of the diploid accessions were selected as parents to study the inheritance pattern of isozymes. The following five hybrid seedling populations were obtained and analyzed for this purpose: selfing of WK2-71-2 (Cross 1), WK2-16-1 × WK2-71-2 (Cross 2), WK2-13-1 ×WK2-70-2 (Cross 3), selfing of WK2-2-1 (Cross 4) and selfing of WK2-16-1 (Cross 5).

The crosses were conducted as follows. Flowering was promoted by gibberellic acid $\left(\mathrm{GA}_{3}\right)$ treatment to bases of petioles of the parental plants (Miyazaki et al., 1986), followed by hand pollination. The seeds were harvested and germinated aseptically on the Murashige and Skoog (1962) medium without hormone. The developing seedlings were transplanted to vinyl pots and grown in a green house.

Enzymes were extracted from young developing leaves and separated electrophoretically on vertical polyacrylamide slab gels or horizontal starch slab gels. The polyacrylamide gel electrophoresis was employed for the separations of aspartate aminotransferase (AAT; EC 2.6.1.1) and shikimate dehydrogenase (SKDH; EC 1.1.1.25) isozymes. The extraction buffer composition was that of Lebot and Aradhya (1991). Seven percent running gel (Tris- $\mathrm{HCl} \mathrm{pH} 8.9$ ) and $4.2 \%$ stacking gel (Tris- $\mathrm{HCl}$ pH 6.7) were used. Tris-glycine pH 8.3 buffer was utilized as the electrode buffer. Gels were run at $15 \mathrm{~mA}$ constant until marker dye (bromophenol blue) migrated to the end of the gel. The starch gel electrophoresis was used for separating glucose-6phosphate isomerase (GPI; EC 5.3.1.9) according to Wendel and Parks (1982) and Wendel (1983). Starch gels were run at $25 \mathrm{~mA}$ constant for six hr. All the electrophoreses were carried out at $4^{\circ} \mathrm{C}$. Enzyme assay for AAT was performed according to Hirai (1988), whereas those for SKDH and GPI were conducted as described by Wendel (1983).

Isozyme loci were tested for single locus Mendelian segregation using chi-square goodness-of-fit values. Contingency chi-square analyses were used for non-random joint segregation.

\section{Results and Discussion}

\section{Genetic systems of AAT, SKDH and GPI isozymes}

Aspartate aminotransferase (AAT) In the progeny of self-pollinated diploid accession (WK2-712), three regions (AAT-1, AAT-2 and AAT-3) of activity were detected for AAT (Fig. 1). Among them, only the most anodal region (AAT-1) clearly represented polymorphism. For the AAT-1 site, selfed progeny of the triple-banded phenotype (Cross 1) produced three classes: 1) a fast migrating single-banded one with a migration distance (MD) $55.0 \mathrm{~mm}$ phenotype; 2) a parental triplebanded phenotye with MD of 55.0, 52.5 and 50.0 $\mathrm{mm}$; and 3) a slow migrating single-banded one

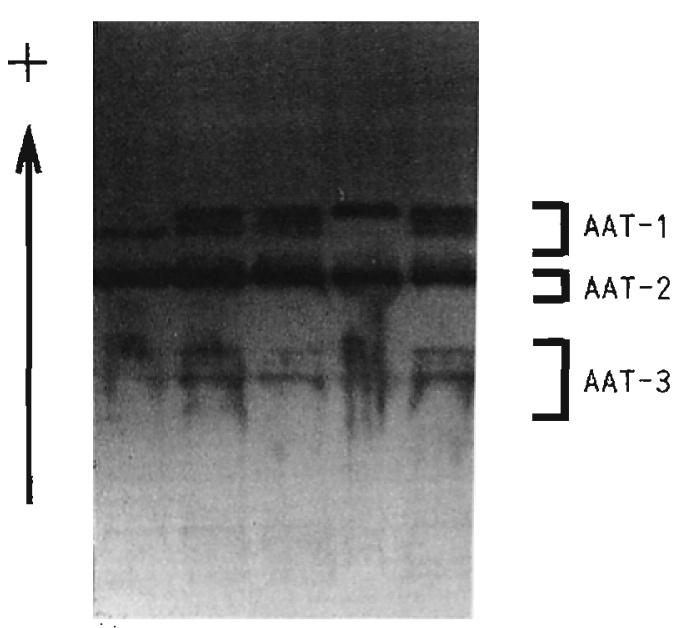

Fig. 1. AAT zymograms of progenies obtained from the selfing of the accession WK2-71-2 (Cross 1). Genotypes at Aat-1 (from left to right) are bb, ab, ab, aa and ab. 
with an $\mathrm{MD}$ of $50.0 \mathrm{~mm}$, in a 1:2:1 ratio (Fig. 1 and Table 1). Cross-pollinated progenies between the triple-banded phenotype and the slow migrating single-banded phenotype (Crosses 2 and 3) segregated into either of the parental phenotypes, in a $1: 1$ ratio (Table 1 ). These segregation ratios do not differ significantly from those of Mendelian expectations. These data are in agreement with the hypothesis that enzymes in AAT-1 are dimeric and a single locus Aat-1 with two alleles codes the activity in this region. The genotypes at Aat.1 could be assigned as $a a, a b$, and bb to the fast migrating single-banded phenotype, the triple-banded phenotype, and the slow migrating single-banded phenotype, respectively.

Shikimate dehydrogenase (SKDH) In the progeny derived from the self-fertilization of WK2-71-2 showing the double bands, single region of activity was recognized for SKDH (Fig. 2). The progeny (Cross 1) exhibited three phenotypes: 1) a fast migrating single-banded (MD $50.0 \mathrm{~mm}$ ) phenotype, 2) double-banded phenotype similar to the parent (MD $50.0 \mathrm{~mm}$ and $45.0 \mathrm{~mm}$ ), and 3 ) a slow migrating single-banded (MD $45.0 \mathrm{~mm}$ ) phenotype, in a 1:2:1 ratio (Table 1). Progenies from a cross-pollination between a double-banded phenotype and the slow migrating single-banded phenotype (Cross 2) segregated to both of parental phenotypes, in the expected 1:1 ratio from the mode of two alleles (Table 1). These data conform to expectations that a single locus $S k d h$ governs a functionally monomeric enzyme in this region and suggest that two alleles ( $b$ and $c$ ) are responsible for the phenotypes. We could assign genotypes bb, bc, and $c c$ to the fast migrating single-banded phenotype, the double-banded phenotype and the slow migrating single-banded phenotype, respectively.

Glucose-6-phosphate isomerase (GPI) The self-fer tilized diploid accession (WK2-71-2) produced two regions (GPI-1 and GPI-2) of activity in the gels stained for GPI (Fig. 3). The most anodal re-

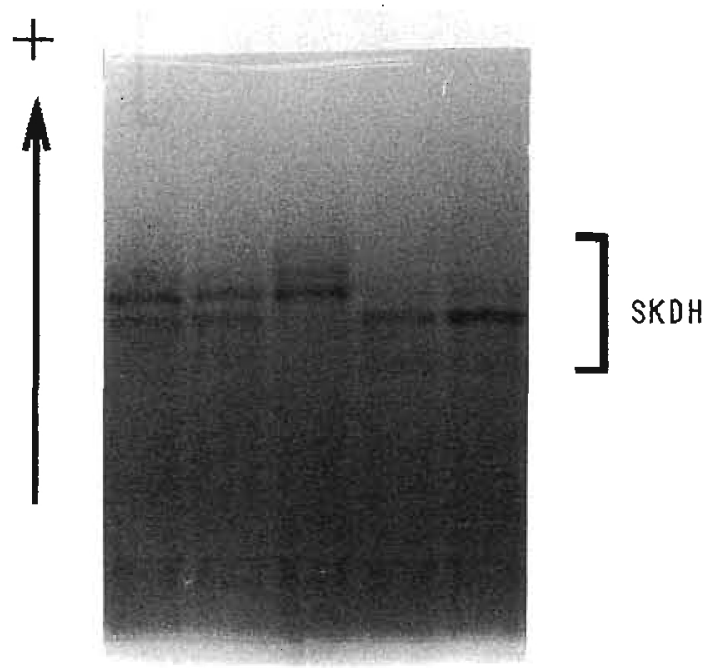

Fig. 2. SKDH zymograms of progenies obtained from the selfing of the accession WK2-71-2 (Cross 1). Genotypes at $S k d h$ (from left to right) are bc, bc, bb. $c c$ and $c c$.

Table 1. Goodness-of-fit test for segregation patterns at three isozyme loci, Aat-1, Skdh and Gpi-2 in the progenies of diploid wild taro.

\begin{tabular}{ccccccc}
\hline \hline Locus & $\begin{array}{l}\text { Cross } \\
\text { number }\end{array}$ & $\begin{array}{l}\text { Parental } \\
\text { genotype }\end{array}$ & \multicolumn{1}{c}{$\begin{array}{c}\text { Progeny } \\
\text { genotype }\end{array}$} & $\begin{array}{l}\text { Expected } \\
\text { ratio }\end{array}$ & $\chi^{2}$ & $P$ \\
\hline \multirow{2}{*}{ Aat.1 } & 1 & $\mathrm{ab} \times \mathrm{ab}$ & $\mathrm{aa}(8): \mathrm{ab}(18): \mathrm{bb}(6)$ & $1: 2: 1$ & 0.75 & $0.70-0.50$ \\
& 2 & $\mathrm{bb} \times \mathrm{ab}$ & $\mathrm{ab}(18): \mathrm{bb}(14)$ & $1: 1$ & 0.50 & $0.50-0.30$ \\
& 3 & $\mathrm{ab} \times \mathrm{bb}$ & $\mathrm{ab}(27): \mathrm{bb}(29)$ & $1: 1$ & 0.07 & $0.90-0.70$ \\
Skdh & 1 & $\mathrm{bc} \times \mathrm{bc}$ & $\mathrm{bb}(9): \mathrm{bc}(15): \mathrm{cc}(8)$ & $1: 2: 1$ & 0.19 & $0.99-0.90$ \\
& 2 & $\mathrm{bb} \times \mathrm{bc}$ & $\mathrm{bb}(19): \mathrm{bc}(13)$ & $1: 1$ & 1.13 & $0.30-0.10$ \\
Gpi-2 & 1 & $\mathrm{ab} \times \mathrm{ab}$ & $\mathrm{aa}(8): \mathrm{ab}(20): \mathrm{bb}(4)$ & $1: 2: 1$ & 3.00 & $0.30-0.10$ \\
& 2 & $\mathrm{ab} \times \mathrm{ab}$ & $\mathrm{aa}(5): \mathrm{ab}(19): \mathrm{bb}(8)$ & $1: 2: 1$ & 1.69 & $0.50-0.30$ \\
& 4 & $\mathrm{ab} \times \mathrm{ab}$ & $\mathrm{aa}(10): \mathrm{ab}(18): \mathrm{bb}(9)$ & $1: 2: 1$ & 0.08 & $0.99-0.90$ \\
& 5 & $\mathrm{ab} \times \mathrm{ab}$ & $\mathrm{aa}(16): \mathrm{ab}(43): \mathrm{bb}(13)$ & $1: 2: 1$ & 2.97 & $0.30-0.10$ \\
\hline
\end{tabular}

$\approx$ 1: Selfing of WK2-71-2, 2: WK2-16-1 ×WK2-71-2, 3: WK2-13-1 $\times$ WK2-70-2, 4: Selfing of WK2-2-1, 5: Selfing of WK2-16-1.

$y$ Number in parenthesis indicates the frequency of progeny. 
gion (GPI-1) did not show clear bands, whereas the most cathodal region (GPI-2) presented clear bands and polymorphism among the progenies, exhibiting a single or triple bands.

All four progeny populations of triple-banded phenotype produced three classes of phenotype, in-

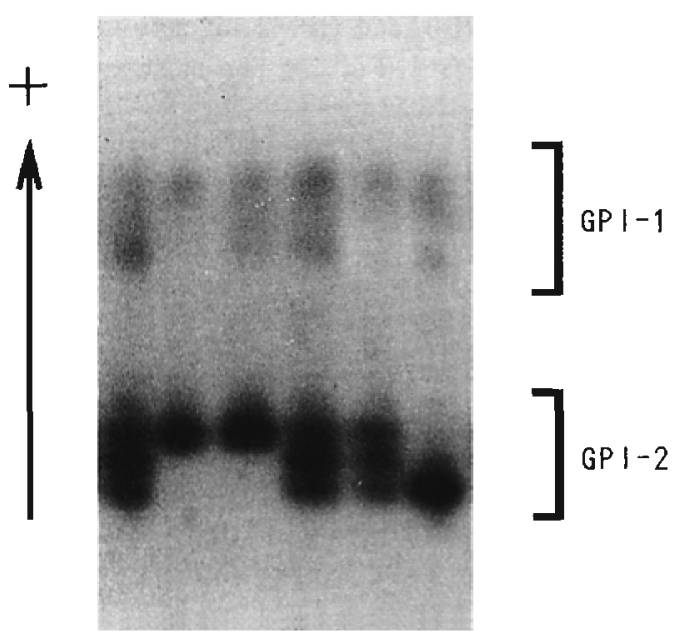

Fig. 3. GPI zymograms of progenies obtained from the selfing of the accession WK2-71-2 (Cross 1). Genotypes at Gpi-2 (from left to right) are ab, aa, aa, $\mathrm{ab}, \mathrm{ab}$ and $\mathrm{bb}$. cluding a fast migrating single-banded (MD 40.0 $\mathrm{mm}$ ) phenotype, a parental triple-banded phenotype and a slow migrating single-banded (MD 30.0 $\mathrm{mm}$ ) phenotype, in a 1:2:1 ratio (Table 1 and Fig. $3)$. The segregation ratios fit those expected by Mendelian model. The segregation data were con. sistent with the hypothesis that enzymes in GPI-2 are dimeric and a single locus Gpi.2 codes the activity in this region (Table 1 ). Two alleles a and $\mathrm{b}$ at $\mathrm{Gpi-2}$ could explain the parental genotypes and segregations of progenies. From these results, genotypes $a \mathrm{a}, \mathrm{ab}$, and $\mathrm{bb}$ could be assigned to the fast migrating single-banded (MD $40.0 \mathrm{~mm}$ ) phenotype, the fast migrating triple-banded (MD 40.0 $\mathrm{mm}, 35.0 \mathrm{~mm}$ and $30.0 \mathrm{~mm}$ ) phenotype, and the slow migrating single-banded $(30.0 \mathrm{~mm})$ phenotype, respectively. Although the segregating progenies gave only the three phenotypes listed above, there was another phenotype among the diploid accessions which exhibited a slow migrating triple-bands consisting of the band governed by allele b at MD $30.0 \mathrm{~mm}$ and those at MD $25.0 \mathrm{~mm}$ and $20.0 \mathrm{~mm}$. Finding that enzymes in GPI-2 are dimeric, we assume that the band at MD $25.0 \mathrm{~mm}$ is heterodimer and the band of MD $20.0 \mathrm{~mm}$ is controlled by another allele (c). We tentatively assign genotype bc to the slow migrating triple-

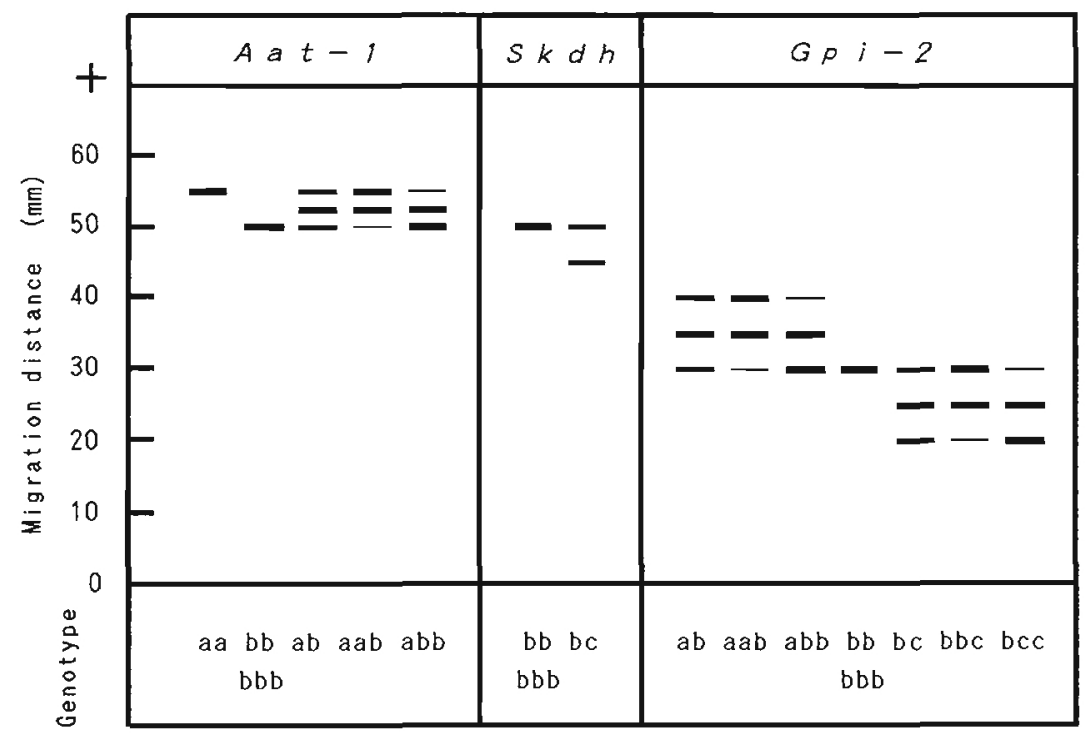

Fig. 4. Schematic illustrations of isozyme bands (above) encoded by $A a t-1, S k d h$ and Gpi-2 and their genotypes (below) observed in the examined 69 accessions. 
banded phenotype, although allelism test of the allele $c$ should be confirmed. Including this bc genotype for GPI-2, the band patterns and their proposed genotypes of the diploid accessions and their progenies for the three loci, are summarized schematically in Fig. 4.

Linkage analysis between Aat-1, Skdh and Gpi-2 The results of contingency chi-square analyses of independent assortment for three pairs between Aat. 1, Skdh and Gpi-2 are prensented in Table 2. No evidence for linkage was detected in the three pairs.

Genetic systems of the three isozyme loci, Aat.1,
Skdh and Gpi-2, were characterized in the wild taro from Bangladesh in the present study. This is the first report that describes genetic systems of isozymes in taro. The isozyme genes revealed here will be useful as genetic markers to study the genetics, systematics, and breeding in taro.

\section{Genetic variations of $A A T, S K D H$ and GPI isozy. mes}

Genotypes at Aat-1, Skdh and Gpi-2 and their frequencies observed in diploid and triploid taro accessions from Bangladesh are presented in Table 3. Although different band intensities due to gene

Table 2. Linkage tests between the three loci, Aat-1, Skdh and Gpi-2.

\begin{tabular}{|c|c|c|c|c|c|}
\hline $\begin{array}{l}\text { Pair of } \\
\text { gene loci }\end{array}$ & $\begin{array}{l}\text { Cross } \\
\text { number }\end{array}$ & $\begin{array}{l}\text { Parental } \\
\text { genotypes }\end{array}$ & Progeny genotype $e^{y}$ & $\chi^{2}$ & $P$ \\
\hline \multirow[t]{3}{*}{ Aat-1/Skdh } & 1 & $a b / b c \times a b / b c$ & $\begin{array}{l}a a / b b: a a / b c: a a / c c: a b / b b: a b / b c: a b / c c: \\
\begin{array}{lllll}\text { (2) } & \text { (3) } & \text { (3) } & \text { (3) } & \text { (11) }\end{array}\end{array}$ & $6.88^{x}$ & $0.70-0.50$ \\
\hline & & & $\begin{array}{l}\mathrm{bb} / \mathrm{bb}: \mathrm{bb} / \mathrm{bc}: \mathrm{bb} / \mathrm{cc} \\
\begin{array}{ll}(4) & \text { (1) (1) }\end{array}\end{array}$ & & \\
\hline & 2 & $\mathrm{bb} / \mathrm{bb} \times \mathrm{ab} / \mathrm{bc}$ & $\begin{array}{l}a b / b b: a b / b c: b b / b b: b b / b c \\
(10) \quad \text { (8) } \\
\begin{array}{lll}(9) & \text { (5) }\end{array}\end{array}$ & $1.75^{\mathrm{w}}$ & $0.70-0.50$ \\
\hline \multirow[t]{3}{*}{ Aat-1/Gpi-2 } & 1 & $a b / a b \times a b / a b$ & $\begin{array}{l}a a / a a: a a / a b: a a / b b: a b / a a: a b / a b: a b / b b: \\
\begin{array}{lllll}(5) & \text { (2) } & \text { (1) } & \text { (1) } & \text { (14) }\end{array}\end{array}$ & $15.00^{x}$ & $0.10-0.05$ \\
\hline & & & $\begin{array}{l}\mathrm{bb} / \mathrm{aa}: \mathrm{bb} / \mathrm{ab}: \mathrm{bb} / \mathrm{bb} \\
\begin{array}{lll}(2) & (4) & (0)\end{array}\end{array}$ & & \\
\hline & 2 & $\mathrm{bb} / \mathrm{ab} \times \mathrm{ab} / \mathrm{ab}$ & $\begin{array}{l}a b / a a: a b / a b: a b / b b: b b / a a: b b / a b: b b / b b \\
\begin{array}{llllll}(3) & (10) & (5) & (2) & (9) & (3)\end{array}\end{array}$ & $2.38^{v}$ & $0.90-0.70$ \\
\hline \multirow[t]{3}{*}{$S k d h / G p i-2$} & 1 & $\mathrm{bc} / \mathrm{ab} \times \mathrm{bc} / \mathrm{ab}$ & $\begin{array}{l}b b / a a: b b / a b: b b / b b: b c / a a: b c / a b: b c / b b: \\
\begin{array}{lllll}(0) & (9) & (0) & (4) & (8)\end{array}\end{array}$ & $13.25^{x}$ & $0.30-0.10$ \\
\hline & & & $\begin{array}{l}c c / a a: c c / a b: c c / b b \\
\begin{array}{ll}\text { (4) } & \text { (3) (1) }\end{array}\end{array}$ & & \\
\hline & 2 & $\mathrm{bb} / \mathrm{ab} \times \mathrm{bc} / \mathrm{ab}$ & $\begin{array}{l}b b / a a: b b / a b: b b / b b: b c / a a: b c / a b: b c / b b \\
\begin{array}{lllll}\text { (3) } & \text { (11) } & \text { (5) } & \text { (2) } & \text { (8) }\end{array}\end{array}$ & $2.88^{\prime \prime}$ & $0.90-0.70$ \\
\hline
\end{tabular}

$z$ See Table 1 .

y Number in parenthesis indicates the frequency of progeny.

- Chi-square goodness-of-fit test to $1: 2: 1: 2: 4: 2: 1: 2: 1$ ratio.

w Chi-square goodness-of-fit test to $1: 1: 1: 1$ ratio.

Chi-square goodness-of-fit test to $1: 2: 1: 1: 2: 1$ ratio.

Table 3. Isozyme genotypes at Aat-1, Skdh and Gpi-2 in diploid and triploid wild taro accessions from Bangladesh.

\begin{tabular}{lll}
\hline \multirow{2}{*}{ Locus } & \multicolumn{1}{c}{ Diploid } & \multicolumn{1}{c}{ Genotype $^{2}$} \\
\hline Aat -1 & $\mathrm{aa}(1), \mathrm{ab}(12), \mathrm{bb}(25)$ & Triploid \\
Skdh & $\mathrm{bb}(34), \mathrm{bc}(4)$ & $\mathrm{abb}$ or abb (24), bbb (7) \\
Gpi-2 & $\mathrm{ab}(9), \mathrm{bb}(22), \mathrm{bc}(7)$ & $\mathrm{abb}(31)$ \\
\end{tabular}

$z$ Number in parenthesis indicates the frequency of accessions. 
dosage effects of alleles were observed occasionally at Aat. 1 and Gpi-2 in heterozygous triploid accessions (Fig. 4), the expressions of the different band intensities could not be scored well. Therefore, the exact genotypes of these accessions could not be determined. Thus, the heterozygous genotypes in the triploid accessions are indicated tentatively as aab or abb at Aat-1, and aab or abb and bbc or bcc at Gpi-2 (Table 3).

At Aat-1, 68 out of the 69 examined accessions had allele b. Allele a was recognized in 13 diploid accessions and in 24 triploid accessions. Only a single diploid accession presented homozygous genotype aa. At $S k d h$, all accessions showed the homozygous genotypes of allele b, except four diploid accessions which exhibited the heterozygous genotype bc; allele $c$ was not recognized in any triploid accessions. At Gpi-2, all accessions possessed allele $\mathrm{b}$; of the 38 diploid accessions, nine contained allele a and seven had allele $c$. In the triploid accessions, seven exhibited allele a whereas 11 had allele $c$.

There are reports that diploid and triploid taro plants could not be distinguished by isozyme patterns in Japanese cultivars (Tanimoto and Matsumoto, 1986) and in the domestic and wild types found in Asia and Oceania (Labot and Aradhya, $1991,1992)$. In our study using the wild taros in Bangladesh, the triploid specific allele was not recognized at the three loci but the diploid accessions contained all the alleles observed in the triploids. This indicates that the component genomes of the triploids might be the same as those of the diploids. Furthermore, the habitats of the wild triploid accessions overlap those of the diploid ones so that the triploid wild taros from Bangladesh may be derivatives from the diploids. This idea supports the previous assumption that taro triploids are auto-triploid (Lebot and Aradhya, 1991. 1992) but to prove the inference, further studies are needed. In our laboratory, a chromosome sur. vey is underway using the progenies obtained from crosses and selfs between the wild diploid accessions in order to examine whether triploids could be obatined from the crosses between diploids.

\section{Acknowledgments}

The authors are very grateful to Dr. M. M. Rashid, Tuberous Crop Research Center, Bangladesh Agricultural Research Institute, for kindly supplying wild taro accessions.

\section{Literature Cited}

Coates, D. J., D. E. Yen and P. M. Gaffey. 1988. Chromosome variation in taro, Colocasia esculenta: Implication for origin in the Pacific. Cytologia 53 : $551-560$.

Hirai, M. 1988. Isozyme analysis of plant. p. 95-99. In: S. Higuchi (ed.). In vitro culture of horticultural plants. Shibata hario garasu Co. Ltd., Tokyo. (In Japanese).

Kuruvilla, K. M. and A. Singh. 1981. Karyotypic and electrophoretic studies on taro and its origin. Euphytica $30: 405-413$.

Lebot, V. and K. M. Aradhya. 1991. Isozyme variation in taro (Colocasia esculenta (L.) Schott) from Asia and Oceania. Euphytica $56: 55-66$.

Lebot, V. and K. M. Aradhya. 1992. Collecting and evaluating taro (Colocasia esculenta) for isozyme variation. Plant Genetic Resources Newsletter 90 : 47-49.

Miyazaki, S., Y. Tashiro, K. Kanazawa, M. Yanagawa and M. Tabaru. 1986. Promotion of flowering by the treatment of seed corms and young plants with gibberellic acid in taros (Colocasia esculenta Schott). J. Japan. Soc. Hort. Sci. $54:$ 450-459.

Murashige, T. and F. Skoog. 1962. A revised medium for rapid growth and bio assays with tobacco tissue cultures. Physiol. Plant. 15 : 473-497.

Plucknett, D. L., R. S. de la Pena and F. Obrero. 1970. Taro (Colocasia esculenta). Field Crop Abstracts $23: 413-426$.

Tanimoto, T. and T. Matsumoto. 1986. Variations of morphological characters and isozyme patterns in Japanese cultivars of Colocasia esculenta Schott and C. gigantea Hook. Japan. J. Breed. 36 : 100-111.

Wendel, J. F. 1983. Electrophoretic analysis of genetic variation in wild and cultivated Camellia japonica L. PhD Thesis, University of North Carolina, Chapel Hill.

Wendel, J. F. and C. R. Parks. 1982. Genetic control of isozyme variation in Camellia japonica L. J. Hered. $73: 197-204$. 
バングラデシュ産野生サトイモ（Colocasia esculenta Schott）のアイソザイムの遺伝様式と変異 一色司郎·中田正洋 · 中村典義·田代洋丞·宮崎貞巳

佐賀大学農学部 840 佐賀市本庄町 1

\begin{abstract}
摘 要
バングラデシュ産野生サトイモの二倍体および三倍 体を用いてアスパラギン酸アミノトランスフェラーゼ (AAT)，シキミ酸デヒドロゲナーゼ（SKDH）および グルコースリン酸イソメラーゼ（GPI）のアイソザイ ムの遺伝様式と变異について解析を行った.

二倍体野生系統間の交配によって得られた 5 種類の 交雑実生群执よび二倍体系統のアイソザイムの多型性 を解析した結果，三つのアイソザイム遺伝子座Aat-1 Skdh およびGpi-2 が同定された。ま，遺伝子座Aat-1 およびSkdhではそれぞれ二つの対立遺伝子が，Gpi-2 では三つの対立遺伝子が存在することが推定された。

これらの三つのアイソザイム遺伝子座間に連鎖は認め られなかった。これらのアインザイムにおける遺伝的 変異はメンデルの法則に従って遺伝することから，サ トイモの遺伝研究，分類㧍よび育種における遺伝的マ 一カーとして利用可能であると考えられる.三倍体系 統は同定された三つのすべての选伝子座において二倍 体系統で認められたものと同じ対立遺伝子のみをもっ ていた。このことから三倍体は二倍体と共通の構成ゲ ノムをもつことが示唆される，従って，バングラデシ エ産野生少トイモの三倍体はその二倍体に由来したも のであると推定される。
\end{abstract}

